\title{
Characterizing Exposures During Laser Tattoo Removal in a Hospital Dermatology Center
}



HHE Report No. 2017-0006-3319

May 2018

Revised August 2019

\author{
Michael P. Grant, ScD \\ Eric Glassford, MS, CIH \\ Brett J. Green, PhD \\ Angela R. Lemons, MS
}




\section{Contents}

Highlights...............................................

Abbreviations ...................................... iii

Introduction ................................... 1

Methods ............................................. 2

Results and Discussion ...................... 4

Conclusions ........................................ 16

Recommendations............................. 16

Appendix A ........................................... 18

Appendix B ....................................... 22

Appendix C .......................................... 23

Appendix D .......................................... 24

Appendix E ............................................. 25

Appendix F .......................................... 27

References.............................................. 34

Acknowledgements........................... 37

Revision Summary: The original final report omitted Table A2 from Appendix A. The revised report corrects this omission and now includes Table A2 - Table of target analytes for metals in air samples during tattoo removal (in $\mu \mathrm{g} / \mathrm{m}^{3}$ )

The employer is required to post a copy of this report for 30 days at or near the workplace(s) of affected employees. The employer must take steps to ensure that the posted report is not altered, defaced, or covered by other material.

The cover photo is a close-up image of sorbent tubes, which are used by the HHE Program to measure airborne exposures. This photo is an artistic representation that may not be related to this Health Hazard Evaluation. Photo by NIOSH. 


\section{Highlights of this Evaluation}

The Health Hazard Evaluation Program received a request from a hospital dermatology center.

The employer was concerned about exposures to the plume produced during laser tattoo removals.

\section{What We Did}

- We evaluated the center in December 2016, February 2017, and July 2017.

- We measured exposures to particles, volatile organic compounds, metals, carbon monoxide, hydrogen sulfide, and bacteria during tattoo removal from both pig skin and patients.

- We asked employees about practices surrounding "laser in use" signs; training practices; and policies surrounding cleaning, storage, and replacing laser protective eyewear.

\section{What We Found}

- Concentrations of metals in personal air samples were all below occupational exposure limits.

- Low levels of acetone, isopropyl alcohol, and xylene in were measured in air samples.

- Particle concentrations were higher in the air around the dermatologist and close to the laser tattoo process as compared to other areas within the patient room.

- Laser tattoo emissions did not migrate out of the patient room.

- We did not detect carbon monoxide or hydrogen sulfide at any time during the tattoo removals.

- Laser eyewear needed replacing.

- Improper use of the "laser in use" signs could lead to accidental eye exposures.

\section{What the Employer Can Do}

We evaluated exposures to dermatologists during laser tattoo removal at a hospital dermatology center. We found low levels of some metals, volatile organic compounds, bacteria, and particles in our air samples. We recommend that the laser safety program be strengthened with accurate use of the "laser in use" signs, replacing damaged laser protective eyewear, and contacting the manufacturer to establish shelf lives and best practices for cleaning and care.

- Work with your Department of Environmental Health and Safety to ensure compliance with the voluntary respiratory protection program standard if voluntary use respirators are provided.

- Contact the manufacturers of the different lasers to establish shelf life, storage conditions, and appropriate cleaning methods for laser safety eyewear.

\section{What Employees Can Do}

- Discontinue use of the laser and molded surgical masks for respiratory protection.

- Only use respirators certified by the National Institute for Occupational Safety and Health.

- Operate the "laser in use" signs only when the laser is in use.

- Report damaged or worn laser protective eyewear to your supervisor. 
This page left intentionally blank 


\section{Abbreviations}

$\begin{array}{ll}\mu \mathrm{g} / \mathrm{m}^{3} & \text { Micrograms per cubic meter } \\ \text { ACGIH® } & \text { American Conference of Governmental Industrial Hygienists } \\ \text { CFR } & \text { Code of Federal Regulations } \\ \text { CPC } & \text { Condensation particle counter } \\ \text { DNA } & \text { Deoxyribonucleic acid } \\ \text { LPE } & \text { Laser protective eyewear } \\ \text { ND } & \text { Not detected } \\ \text { nm } & \text { Nanometer } \\ \text { NIOSH } & \text { National Institute for Occupational Safety and Health } \\ \text { OEL } & \text { Occupational exposure limit } \\ \text { OSHA } & \text { Occupational Safety and Health Administration } \\ \text { p/cc } & \text { Particles per cubic centimeter } \\ \text { PCR } & \text { Polymerase chain reaction } \\ \text { ppb } & \text { Parts per billion } \\ \text { PPE } & \text { Personal protective equipment } \\ \text { rDNA } & \text { Ribosomal deoxyribonucleic acid } \\ \text { TLV } & \text { Threshold limit value } \\ \text { VOC } & \text { Volatile organic compound }\end{array}$


This page left intentionally blank 


\section{Introduction}

The Health Hazard Evaluation Program received a request from the manager of a dermatology center at a hospital in Massachusetts. The employer was concerned about dermatologist's exposures to the plume created during laser tattoo removal. We visited the center in December 2016, February 2017, and July 2017 to assess exposures to metals, volatile organic compounds (VOCs), particles, bacteria, carbon monoxide, and hydrogen sulfide. We also observed work practices and airflow patterns.

\section{Background}

We visited the center on three different occasions to observe work practices and perform environmental sampling during laser tattoo removal. In February 2017, we assessed exposures to a dermatologist performing laser tattoo removal from slabs of pig skin. This is a routine activity of the position, as dermatologists use this method to practice removing tattoos, and to test new lasers and techniques. Tattoo removal using pig skin provides a similar experience to removing tattoos from human skin. As the dermatologists first tattoo the pig skin, it also allows for the knowledge of exactly which ink was in the tattoo. Ink type is not typically known when tattoo removal occurs in human patients. In July 2017, we assessed exposures to a dermatologist performing laser tattoo removal from patients.

The laser tattoo removal process generally requires multiple treatments after an initial consultation. Each treatment removes some of the ink particles in the skin. Treatments are typically at least two weeks apart from each other to allow the skin to heal before the next laser application. The duration of a laser tattoo removal depends on the size of the tattoo. Smaller tattoo removals last only a few minutes while larger tattoos could take 30-45 minutes. After the procedure, the dermatologist cleaned the tattoo with isopropyl alcohol and applied a cream. The laser tattoo removals are performed in a generic patient examination room. The examination room has an adjustable chair for the patient to sit in and an overhead light (Figure 1). The laser tattoo removal machines are portable and can be wheeled into the appropriate examination room to the side of an adjustable examination chair for easy patient access. Multiple laser machines were used, depending on the wavelength and power of the laser desired. The laser machines were operated at various pulse rates and wavelengths. The machines used either specific pulse rates (picosecond or nanosecond) or variable pulse rates (q-switched). Laser wavelengths used included 532 nanometer $(\mathrm{nm}), 694 \mathrm{~nm}, 755 \mathrm{~nm}$, or 1,064 nm wavelengths. The color of the tattoo was a primary factor in the choice of pulse rate and wavelength. Different colored ink and skin tones react differently to specific wavelengths. 


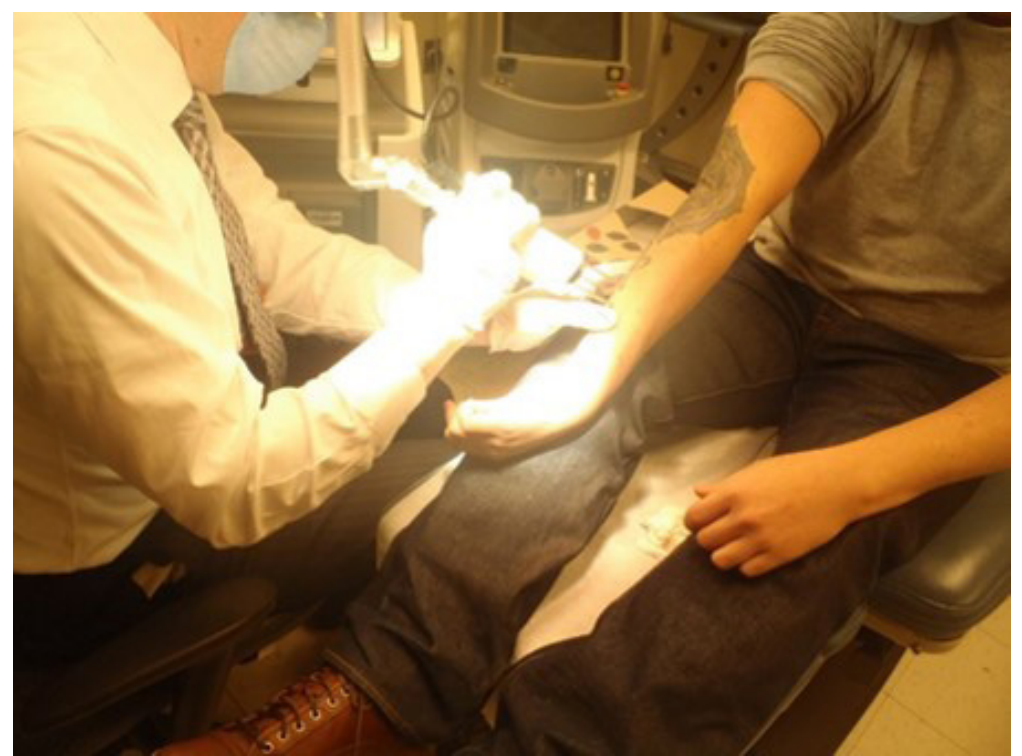

Figure 1. Dermatologist using a laser probe to remove a tattoo. Photo by $\mathrm{NIOSH}$.

Typically, patients will schedule a consultation with a dermatologist in order to explore tattoo removal options. If the patient is eligible for a removal and decides to undergo the procedure, the procedure is performed on the same day unless there are scheduling conflicts with the patient. This clinic can perform anywhere from one to five tattoo removals on an average day. The exact number can vary considerably depending on how many patients are seeking tattoo removals. Dermatologists perform other procedures during the day, not just tattoo removals.

The employer was concerned about the contents of the plume produced during laser tattoo removal. We evaluated exposures to metals, VOCs, particles, carbon monoxide, hydrogen sulfide, and bacteria. We chose these targets for assessment because they were the most likely components of the plume produced during laser tattoo removal. It is known that tattoo inks often contain metals [Forte et al. 2009]. The action of using a laser to enter the skin and heat up ink particles has a high likelihood of producing VOCs by burning skin, hair, and ink components. When a laser is applied to tattoo ink, the laser targets the ink particles and either breaks them down into smaller particles or expels them from the skin [Ho et al. 2002]. Carbon monoxide has been detected in the plume produced during laser hair removal, which is a similar skin and hair burning process to tattoo removal [Chuang et al. 2016]. Hydrogen sulfide can interfere with carbon monoxide measurements so we measured for both substances simultaneously. Bacterial genetic material has been identified in smoke plumes from other types of laser treatments [Sawchuck et al. 1989].

\section{Methods}

The objective of this project was to characterize the plume produced during laser tattoo removals. To accomplish this objective we assessed exposures to (1) metals, (2) VOCs, (3) particulates, (4) bacteria, (5) carbon monoxide, and (6) hydrogen sulfide.

In order to account for the variable frequency of tattoo removals on any given day, the clinic had scheduled multiple consecutive patient tattoo removals to happen after the clinic was closed. There were no tattoo removals performed during the normal business hours of the clinic. 
We had three main sampling locations: (1) air samples collected in or near the breathing zone of the dermatologist performing the tattoo removals; (2) area air samples collected in the patient room near where an attendant (an additional dermatologist or nurse) would be located during tattoo removal procedures; and (3) area air samples collected at an employee workstation outside of the patient room to determine if the emissions could migrate. These sampling locations were the same for all exposures that were assessed.

\section{Metals}

Prior to our arrival in February 2017, the dermatologist tattooed five slabs of pig skin with different ink colors. We took bulk samples of each of the tattoo inks used and analyzed them for metals according to National Institute for Occupational Safety and Health (NIOSH) Method 7303 [NIOSH 2018]. A list of target analytes for the bulk sample analysis is in Appendix A, Table A1.

We collected personal air samples for metals in the breathing zone of the dermatologist performing tattoo removals from pig skin (February 2017) and from actual patients (July 2017). We analyzed the air samples for metals according to NIOSH Method 7303 [NIOSH 2018]. Lists of target analytes for the air sample analyses are in Appendix A, Table A2.

\section{Volatile Organic Compounds}

We collected area air samples using 1.4 liter evacuated canisters and analyzed them according to Environmental Protection Agency method TO-15 [EPA 1999]. These area air samples were collected both inside and outside of the patient room during the entire removal process, for each type of tattoo removal. Instantaneous samples for each type of tattoo removal were collected directly above the laser probe, while the tattoo was being removed. The flow controllers used for area air sampling were designed for a 2 hour (pig skin removals) and 4 hour (patient removals) sampling duration. The flow controllers for instantaneous sampling were designed for a short sampling duration (less than 30 seconds). Lists of the 65 target analytes are in Appendix A, Table A3. Additional compounds were tentatively identified using the Wiley Registry 9th edition/National Institute of Standards and Technology 2008 mass spectral library.

\section{Particulate Air Sampling}

We used direct-reading instruments to measure airborne particulate in real time during the tattoo removals. We used a TSI® model 3007 handheld condensation particle counter (CPC) to measure ultrafine particle number concentrations and a TSI SidePak Personal Aerosol Monitor (SidePak) to measure particulate mass concentrations. In addition to the area samples, we used another CPC to measure particle number concentrations closer to the tattoo removal process, where the dermatologist was positioned. The inlet was positioned in the breathing zone of the dermatologist.

We also collected personal samples of respirable particulate mass concentrations during the tattoo removal process. We placed a SidePak attached to a cyclone sampler in the breathing zone of the dermatologist during the tattoo removal to evaluate personal exposure to the respirable mass concentrations. Respirable particles are those that can reach the alveolar region (deepest region) of the lung when inhaled. 


\section{Bacterial Exposures}

During laser tattoo removals from patients, we used a NIOSH two-stage bioaerosol sampler [Lindsley et al. 2006]. We collected personal and area air samples during the tattoo removals from patients. Further details of the sampling and microbiological diversity analysis are in Appendix B. Briefly, we used deoxyribonucleic acid (DNA) to identify varieties of bacteria by comparing our sequence results to the National Center for Biotechnology Information database. We did not measure bacterial exposures during laser tattoo removals from pig skin.

\section{Carbon Monoxide and Hydrogen Sulfide}

We took area and personal measurements using BW Honeywell, GasAlert Extreme single gas monitors to measure carbon monoxide and hydrogen sulfide during the tattoo removals.

\section{Results and Discussion}

During our visit in February 2017, the dermatologist removed tattoos from five slabs of pig skin. Each slab was tattooed using a different, known color and brand of ink. The removal time ranged from one to eight minutes. During each removal, the laser was operated at a specific wavelength and pulse rate (Appendix C, Table C1). During our visit in July 2017, the dermatologist removed 6 tattoos from 5 patients over two days. The removal time ranged from 3 to 19 minutes depending on the size of the tattoo. Some patients had tattoos with multiple colors or had multiple tattoos being removed. The wavelength and pulse rate used depended on the colors of the tattoo (Appendix C, Table C2).

\section{Metals}

\section{Laser Tattoo Removal from Pig Skin}

The results of the metals analysis for the bulk tattoo ink samples are presented in Appendix D, Table D1. All inks tested had detectable amounts of metals in them.

The task-based personal air samples had low levels of aluminum, copper, manganese, phosphorus, potassium, titanium, and zirconium (Table 1). If the dermatologist were to perform this task for a full day, then they would be well below the lowest occupational exposure limits (OELs) for each analyte set by the Occupational Safety and Health Administration (OSHA), NIOSH, and the American Conference of Governmental Industrial Hygienists (ACGIH). For more information about OELs, refer to Appendix E. We found magnesium and potassium in the area air sample collected in the patient room. Potassium does not have an OEL. We found titanium in the area air sample from an employee workstation outside the patient room. Other metals were not detected. OSHA, NIOSH, and ACGIH do not have OELs for area air samples. 
Table 1. Air samples for elements while the dermatologist is performing tattoo removals from pig skin (in $\left.\mu \mathrm{g} / \mathrm{m}^{3}\right)^{*} \dagger$

\begin{tabular}{lccc}
\hline Analyte & Breathing zone & Area inside patient room§ & Waiting room \\
\hline Aluminum & {$[1.1]$} & $\mathrm{ND}$ & ND \\
Copper & {$[0.27]$} & $\mathrm{ND}$ & $\mathrm{ND}$ \\
Manganese & {$[0.04]$} & {$[5.0]$} & $\mathrm{ND}$ \\
Phosphorus & {$[1.3]$} & $\mathrm{ND}$ & $\mathrm{ND}$ \\
Potassium & {$[2.0]$} & {$[0.82]$} & $\mathrm{ND}$ \\
Titanium$^{* *}$ & {$[0.61]$} & $\mathrm{ND}$ & 0.47 \\
Zirconium $^{\text {Zirco }}$ & {$[0.06]$} & $\mathrm{ND}$ & $\mathrm{ND}$ \\
\hline
\end{tabular}

[ ] = Estimated concentration; this concentration was between the minimum detectable concentration and the minimum quantifiable concentration.

$\mu \mathrm{g} / \mathrm{m}^{3}=$ Micrograms per cubic meter

ND $=$ Not detected

*The minimum detectable and quantifiable concentrations are listed in Appendix A, Table A2.

†The duration of these samples were 91-96 minutes.

$\ddagger$ Personal breathing zone samples taken within the breathing zone of the dermatologist.

$\S$ Area air samples for elements in the patient room near where an attendant would be located.

IArea air sample from an employee workstation outside the patient room.

${ }^{* *}$ As titanium dioxide

\section{Laser Tattoo Removal from Patients}

The personal air samples collected from patients contained low levels of manganese, potassium, and zinc (Table 2). If the dermatologist were to perform this task for a full day, then they would be well below the lowest OELs for each analyte set by OSHA, NIOSH, and ACGIH. For more information about OELs, refer to Appendix E. We found beryllium, potassium, vanadium, and zinc in the area air sample collected in the patient room near where an attendant would be located. We found lithium and potassium in the area air sample from an employee workstation outside the patient room. Other metals were not detected. 
Table 2. Air samples for elements while the dermatologist is performing tattoo removals from patients $\left(\text { in } \mu \mathrm{g} / \mathrm{m}^{3}\right)^{*} \dagger$

\begin{tabular}{lccc}
\hline Analyte & Breathing zone $\neq$ & Area inside patient room§ & Waiting room I \\
\hline Day 1 & & & \\
$\quad$ Lithium & $\mathrm{ND}$ & $\mathrm{ND}$ & {$[0.07]$} \\
Potassium & 5.3 & $\mathrm{ND}$ & 4.9 \\
Beryllium & $\mathrm{ND}$ & {$[0.01]$} & $\mathrm{ND}$ \\
Vanadium & $\mathrm{ND}$ & {$[0.43]$} & $\mathrm{ND}$ \\
Zinc & $\mathrm{ND}$ & {$[0.51]$} & $\mathrm{ND}$ \\
Day 2 & & & \\
$\quad$ Manganese & {$[0.22]$} & $\mathrm{ND}$ & $\mathrm{ND}$ \\
Potassium & 8.2 & 8.4 & 7.6 \\
Zinc & {$[0.56]$} & $\mathrm{ND}$ & $\mathrm{ND}$ \\
\hline
\end{tabular}

[ ] = Estimated concentration; this concentration was between the minimum detectable concentration and the minimum quantifiable concentration.

*The minimum detectable and quantifiable concentrations are listed in Appendix A, Table A2. †The duration of these samples were 91-93 minutes on day one and 47-50 minutes on day two. $\ddagger$ Personal breathing zone samples taken within the breathing zone of the dermatologist.

§Area air samples for elements in the patient room near where an attendant would be located. TArea air sample from an employee workstation outside the patient room.

${ }^{* *}$ As titanium dioxide

Overall, there were fewer metals detected in the air samples taken during tattoo removals from patients, than from pig skin. This may be due to the natural processes whereby the immune system attacks tattoo pigment particles [Grant et al. 2015]. Over time, this allows the tattoo to become more "permanent" as any particles that were small enough to be removed through natural processes have been excreted. The remaining pigment particles are more difficult to remove from the skin, even when using a laser. Since the pig skin tattoos were applied to dead skin, there is no immune system response to begin the process of removing pigment particles. Thus, it is not surprising to see more metal particles in the air when the ink was removed from the pig skin compared to patients where the tattoos were much older and applied to living tissue. Regardless, concentrations seen in both removal scenarios were below established OELs.

\section{Volatile Organic Compounds}

\section{Laser Tattoo Removal from Pig Skin}

To assess VOCs in the air, we collected three area samples (approximately 90 minutes each) and nine instantaneous samples (approximately 30 seconds each). We found several detectable but not quantifiable VOCs in the area air samples collected (Table 3). We found quantifiable, but low levels of several VOCs including isopropyl alcohol, acetone, propene, ethyl acetate, and toluene. 
We found VOCs in all but one of the instantaneous samples collected. The type and number of compounds detected varied depending on the wavelength of the laser and color of the ink in the tattoo. See Appendix F, tables F1-F5 for more details. In addition to the VOCs listed in the tables, 51 other chemicals were tentatively identified in the canister air samples.

Table 3. Air samples for VOCs while the dermatologist is performing tattoo removal from pig skin (in ppb)*†

\begin{tabular}{|c|c|c|c|}
\hline Analyte & $\begin{array}{c}\text { Area near } \\
\text { breathing zone } \neq\end{array}$ & $\begin{array}{c}\text { Area inside } \\
\text { patient room§ }\end{array}$ & Waiting room \\
\hline 1,2,4-Trimethylbenzene & ND & {$[0.12]$} & {$[0.19]$} \\
\hline 2,2,4-Trimethylpentane & ND & {$[0.24]$} & {$[0.35]$} \\
\hline 2-Butanone & ND & {$[0.49]$} & {$[0.78]$} \\
\hline Acetone & 26 & 21 & 18 \\
\hline Benzene & {$[0.57]$} & {$[0.51]$} & {$[0.59]$} \\
\hline Carbon disulfide & ND & ND & {$[0.21]$} \\
\hline Chloromethane & {$[0.73]$} & {$[0.69]$} & {$[0.66]$} \\
\hline Dichlorodifluoromethane & {$[0.52]$} & [0.53] & {$[0.52]$} \\
\hline Ethyl acetate & [0.18] & {$[0.16]$} & 1.6 \\
\hline Ethylbenzene & {$[0.18]$} & {$[0.22]$} & {$[0.59]$} \\
\hline Heptane & ND & {$[0.12]$} & {$[0.40]$} \\
\hline Hexane & {$[0.20]$} & {$[0.22]$} & ND \\
\hline Isopropyl alcohol & 9,600 & 2,000 & 14,000 \\
\hline m \& p-Xylene & {$[0.57]$} & {$[0.65]$} & [1.9] \\
\hline Methylene chloride & {$[0.30]$} & {$[0.26]$} & {$[0.28]$} \\
\hline o-Xylene & {$[0.20]$} & {$[0.22]$} & {$[0.54]$} \\
\hline Propene & 1.7 & 1.8 & 2.0 \\
\hline Toluene & {$[0.75]$} & {$[0.77]$} & 1.2 \\
\hline Trichlorofluoromethane & {$[0.68]$} & {$[0.65]$} & {$[0.64]$} \\
\hline
\end{tabular}

[ ] = Estimated concentration; this concentration was between the minimum detectable concentration and the minimum quantifiable concentration.

$\mathrm{ppb}=$ Parts per billion

*The minimum detectable and quantifiable concentrations are listed in Appendix A, Table A3.

†The duration of these samples were 89-92 minutes.

$\ddagger$ Personal breathing zone samples taken within the breathing zone of the dermatologist.

§Area air samples for elements in the patient room near where an attendant would be located.

TArea air sample from an employee workstation outside the patient room. 


\section{Laser Tattoo Removal from Patients}

We took six area samples during the entire removal process and nine instantaneous samples. We found low levels of several VOCs in the area air samples collected including acetone, ethylbenzene, isopropyl alcohol, and $\mathrm{m} \& \mathrm{p}$-xylene (Table 4).

We found VOCs in all of the instantaneous samples collected. The type and number of compounds detected varied depending on the wavelength of the laser and color of the ink in the tattoo. We expected to see VOCs in all of the instantaneous samples because of the nature of the laser tattoo removal process. Different inks and lasers produced different VOCs, all at very low concentrations. See Appendix F, Tables F6-F9 for more details. In addition to the VOCs listed in the tables, 28 other chemicals were tentatively identified in the canister air samples.

Although there were some differences in the results from the area air samples between days one and two (Table 4), we saw similar concentrations of the same analytes on both days and in all locations. Black tattoos tended to have the same analytes detected in the instantaneous samples (see Appendix F, Table F6). Variability in the concentrations can be attributed to the inherent biological and physiological differences between patients. Additionally, each tattoo was different (i.e., age, type and density of ink, location on the body) so we would expect to see differing concentrations. There were also similar results for the instantaneous samples during removal of blue/green tattoos (see Appendix F, Table F9). The red and yellow tattoo removals used the same wavelength of laser so it is not surprising that there were similar analytes detected in each sample (see Appendix F, Tables F7 and F8). There are larger differences in concentrations detected in these samples compared to the comparisons of the black or blue/green samples. The larger variations in type and concentration of analytes detected in these samples is likely due to the different colored ink in addition to the differences between patients and tattoos mentioned above. 
Table 4. Air samples for elements while the dermatologist is performing tattoo removals from patients $\left(\text { in } \mu \mathrm{g} / \mathrm{m}^{3}\right)^{\star} \dagger$

\begin{tabular}{lccc}
\hline Analyte & Breathing zone $\neq$ & Area inside patient room§ & Waiting room $\mathbb{}$ \\
\hline Day 1 & & & \\
Acetone & 35 & 35 & 23 \\
Ethyl acetate & {$[3.4]$} & {$[4.0]$} & {$[4.9]$} \\
Ethylbenzene & {$[5.7]$} & {$[5.6]$} & 13 \\
Isopropyl alcohol & 5,800 & 5,100 & 4,800 \\
m \& p-Xylene & 16 & 16 & 35 \\
o-Xylene & {$[3.4]$} & {$[3.4]$} & 7.5 \\
Day 2 & & & \\
Acetone & 28 & 29 & 140 \\
Ethyl acetate & $N D$ & $N D$ & {$[4.5]$} \\
Ethylbenzene & 23 & {$[8.6]$} & {$[9.8]$} \\
Isopropyl alcohol & 3,900 & 4,300 & 4,300 \\
m \& p-Xylene & 39 & 26 & 29 \\
o-Xylene & {$[11]$} & {$[5.8]$} & {$[6.8]$} \\
\hline
\end{tabular}

[ ] = Estimated concentration; this concentration was between the minimum detectable concentration and minimum quantifiable concentration.

*The minimum detectable and quantifiable concentrations are listed in Appendix A, Table A2.

†The duration of these samples was 90 minutes on day one and 48 minutes on day two.

$\ddagger$ Personal breathing zone samples taken within the breathing zone of the dermatologist.

§Area air samples for elements in the patient room near where an attendant would be located.

TArea air sample from an employee workstation outside the patient room.

\section{Direct-reading Particulate Air Sampling}

\section{Laser Tattoo Removal from Pig Skin}

We measured peaks in particle concentrations that corresponded to the starting and stopping times of the tattoo removal process. Figure 2 shows the particle concentrations from CPC data collected in the patient room during pig skin removal where the attendant would be located as compared to the employee workstation outside of the patient room. Particle concentrations sharply increased when a tattoo removal was started. When the process was stopped to change laser configurations or change pig skin tattoo samples with new colors, the particle concentrations in the patient room declined. Information on the tattoo color, laser wavelength, pulse rate, and duration are provided in Appendix $\mathrm{C}$, Table $\mathrm{C} 1$. The tattoo removals ranged from one to eight minutes. 


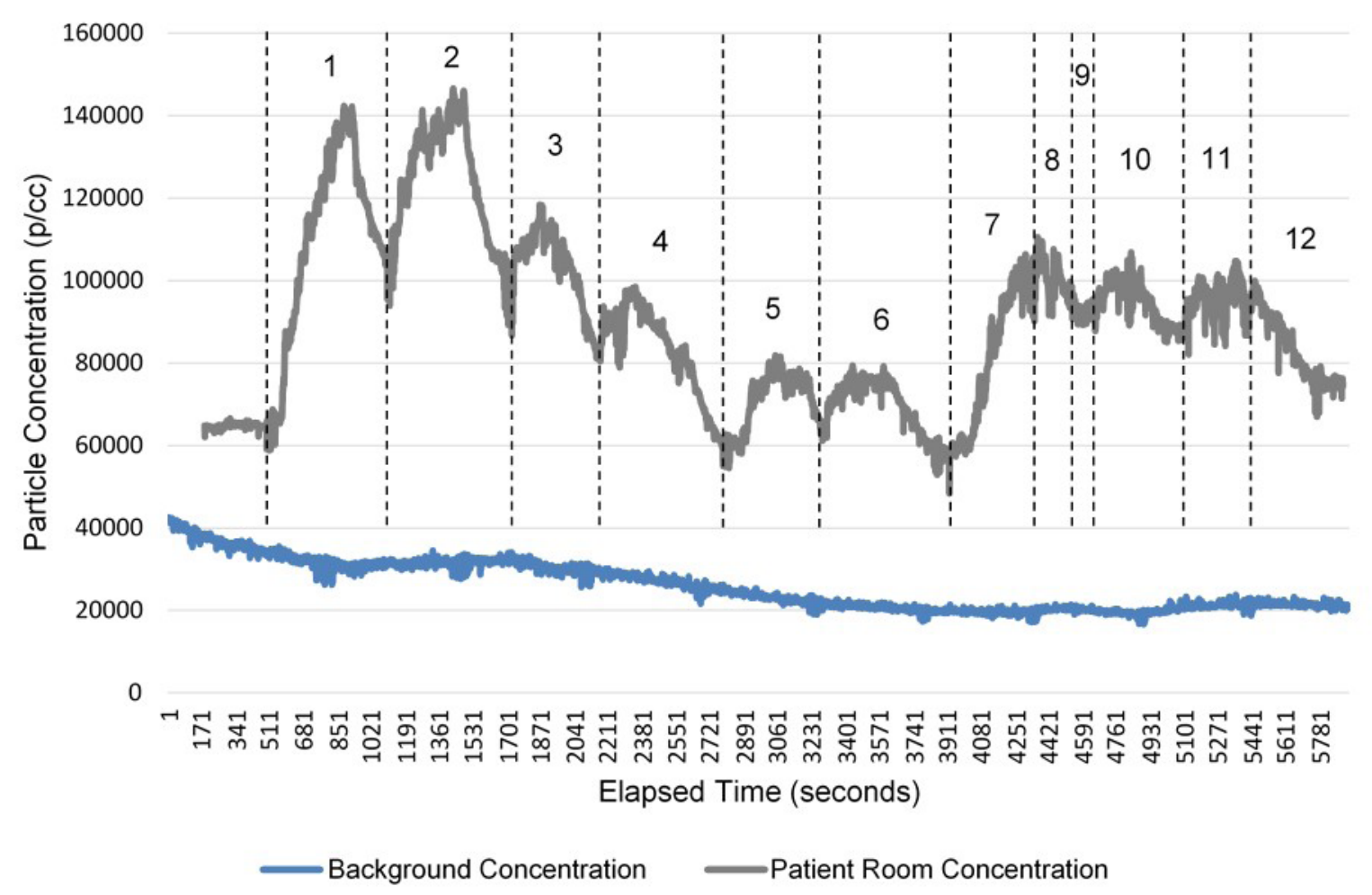

Figure 2. Particle concentration comparison between the patient room and the employee workstation areas, from CPC data. The dark gray line shows particle concentrations where an attendant would be located. The blue line represents particle concentrations at the employee workstation outside of the patient room. We identified 12 notable peaks that related to starting and stopping times of tattoo removal on pig skin.

The mean particle number concentration inside the patient room during the tattoo removal on pig skin was approximately 91,000 particles per cubic centimeter $(\mathrm{p} / \mathrm{cc})$, and ranged from $48,000-147,000 \mathrm{p} / \mathrm{cc}$. This was several times higher than particle concentrations measured outside the room in the employee workstation area, which ranged from 20,000-30,000 p/cc during the process. The average particulate mass concentrations inside the patient room was $61 \mu \mathrm{g} / \mathrm{m}^{3}$, which was approximately five times higher than outside the room at the employee workstation (average $12 \mu \mathrm{g} / \mathrm{m}^{3}$ ). Particulate mass and number concentrations measured at the employee workstation did not show similar peaks or fluctuations that corresponded to tattoo start and stop times. Therefore, we did not find any evidence indicating that tattoo emissions were migrating out of the patient rooms during the removal process. Personal air sampling for respirable particle mass concentrations during pig skin tattoo removal averaged $70 \mu \mathrm{g} / \mathrm{m}^{3}$ over the 90 minutes of sampling.

We also placed a CPC on the patient chair a few inches away from the pig skin, on the right side of the dermatologist. At various times during the laser tattoo removal, we moved the $\mathrm{CPC}$ to see if any changes occurred in particle concentrations based on location. When we moved the CPC to the left side of the dermatologist (between the tattoo being removed 
and the laser removal unit), we noticed particle concentrations increased 3-4 times when compared to the right side of the dermatologist (Figure 3). We believe this may have been from the cooling fan of the laser, which was pulling air toward the unit and was located on the left side of the dermatologist.

Overall, the real-time particulate air sampling data shows that the laser tattoo process increased the amount of airborne particles near the dermatologist during pig skin tattoo removal, as compared to other locations within or outside of the room.

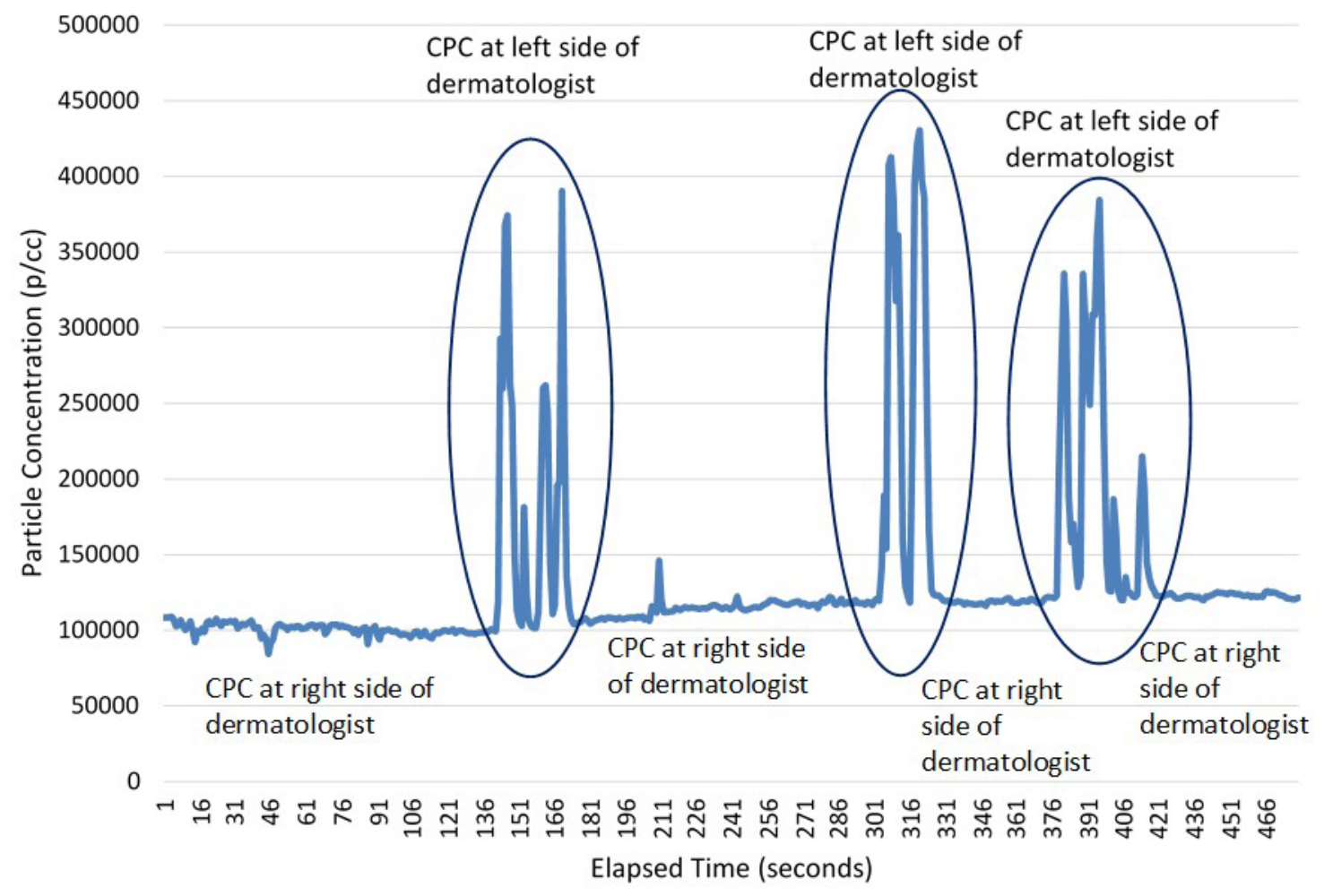

Figure 3. CPC data showed dramatic increases in particle concentrations from one side of the dermatologist compared to the other. Particle concentrations increase by 3-4 times when we measured on the left side of the dermatologist compared to the right side.

\section{Laser Tattoo Removal from Patients}

Personal air sampling for respirable particulate mass concentrations averaged $21 \mu \mathrm{g} / \mathrm{m}^{3}$ on day one over 90 minutes, and $11 \mu \mathrm{g} / \mathrm{m}^{3}$ on day two over 45 minutes. While brief increases (peaks) in particulate mass concentrations occurred several times throughout the sampling periods, we did not see any pattern that would match the timing of the laser tattoo removals.

We saw particle concentrations in the patient room rapidly increase with peaks when we moved the roaming $\mathrm{CPC}$ close to the tattoo removal process. Peaks occurred when we positioned the 
CPC on both sides of the dermatologist, near the dermatologist's breathing zone, near the tattoo removal site, and directly above the tattoo site. These increases in particle concentrations again show that the area around the laser tattoo removal site has increased particle concentrations, including where the dermatologist is situated during the removal process. In contrast to the pig skin tattoo removal, we saw an increase in particle number concentrations on both sides of the dermatologist, not just the left side. We believe that the difference during patient tattoo removals could be due to the dermatologist moving around more and also that the patient's body may be causing changes in the airflow direction.

There were no observable peaks detected at the attendant location in the patient room. Average particle concentrations were approximately 3,000 p/cc on both days of sampling. We also did not see patterns in particulate mass and number concentrations in the waiting room area that would indicate laser tattoo removal emissions are escaping the patient room. On average, particulate mass and number concentrations in the employee workstation were lower than the patient room.

Between the two different types of laser tattoo removal processes, we noticed that particle number and mass concentrations were highest near the dermatologist and the tattoo removal site. However, laser tattoo removal from pig skin had almost 30 times higher particle concentrations in the patient room compared to human tattoo removal. For both types of tattoo removal, particle concentrations did not seem to migrate outside of the patient room.

\section{Bacterial Exposures during Laser Tattoo Removal from Patients}

We collected two personal and four area air samples for bacteria. On day one, the personal air sample was collected for 93 minutes and the area air samples were collected for 91 minutes. On day two, the personal air sample was collected for 50 minutes and the area air samples were collected for 48 minutes. The results are reported as the relative abundance, which is the percentage of each bacteria phylum and class out of the total number of DNA sequences identified in the analysis. Bacterial clones were clustered into 27 operational taxonomic units. Bacterial sequences identified in the field and media negative control samples were subtracted from the results. A total of 5 bacterial phyla and 8 classes were identified in the analysis (Figure 4). The bacterial phyla identified were Actinobacteria, Bacteroidetes, Firmicutes, Fusobacteria, and Proteobacteria (Figure 4A). The gram-positive phylum, Firmicutes, was the most frequently detected phyla (41\%) and consisted of sequences placed in the classes Bacilli (19.1\%) and Clostridia (21.4\%) (Figure 4B). Sequences derived from the Firmicutes comprised $63 \%$ and $43 \%$ of bacterial sequences identified in the employee workstation and personal breathing zone samples, respectively (Figure 5). Other commonly detected phyla were the Proteobacteria (26\%) that was prevalent in patient room samples, whereas sequences derived from the Bacteroidetes accounted for 38\% and $25 \%$ of bacterial sequences in employee workstation and personal breathing zone samples, respectively (Figure 5). OSHA, NIOSH, and ACGIH do not have OELs for bacteria. 
A

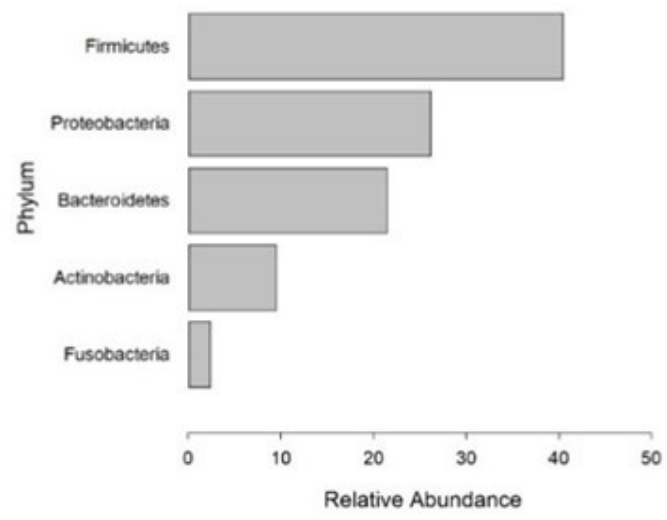

B

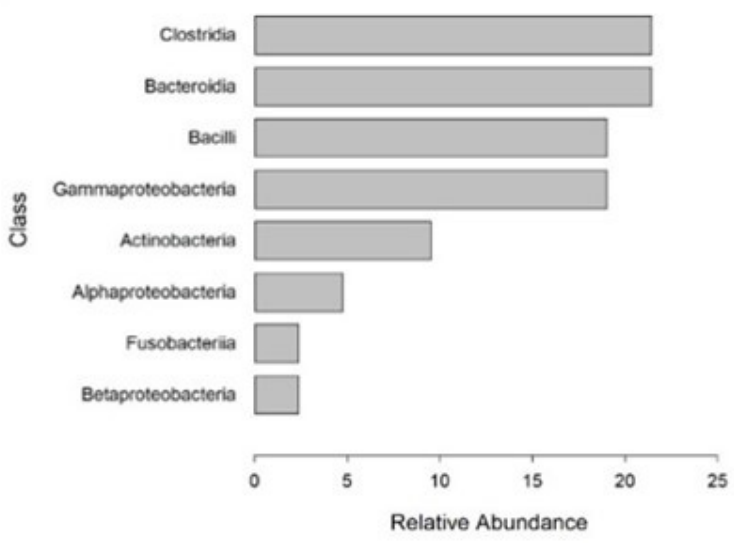

Figure 4. Relative abundance of bacterial phylum (A) and class (B) detected in area air samples during laser tattoo removal, across all samples collected. 


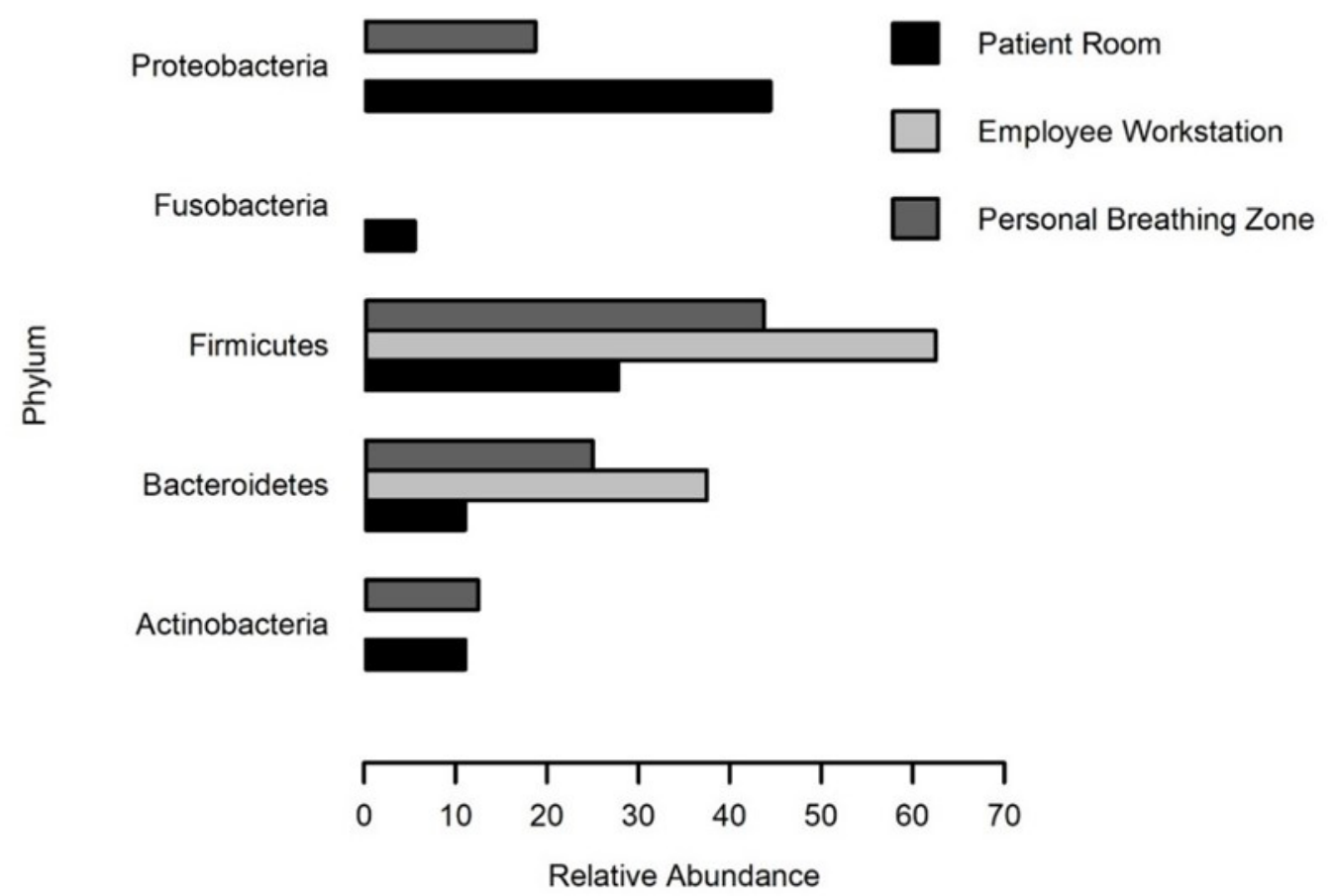

Figure 5. Relative abundance of five bacterial phylum detected in each of the three sampling locations.

Actinobacteria, Fusobacteria, and Proteobacteria were found in the air samples taken in the patient examination room, but not in the air samples taken at the employee workstation. Actinobacteria are commonly found on the skin [Grice and Segre 2011]. Fusobacteria are commonly associated with topical skin ulcers and the normal flora of the oropharynx [Riordan 2007]. Although the dermatologist did not note topical skin ulcers, it is possible that they were not detected during the intake examination. Proteobacteria have been found to be the dominant microbe in human skin [Grice et al. 2008]. Detecting these phyla in the patient room but not outside of the patient room could indicate that they were present due to the laser tattoo removals. It is also possible that these phyla were detected because there were more people inside the patient room than outside the room. Bacteroidetes and Firmicutes are widely found in the environment and are common gut flora [Grice and Segre 2011]. It is not surprising to find Bacteroidetes and Firmicutes in the area air samples at the employee workstation outside of the patient room and not inside of the patient room. The patient room is cleaned more thoroughly and frequently than the other areas of the clinic.

\section{Carbon Monoxide and Hydrogen Sulfide}

We did not detect carbon monoxide or hydrogen sulfide at any time during the tattoo removals from pig skin or patients. We sampled for both gases over the entire duration of the tattoo removal activities (approximately 90 minutes on day one and approximately 45 minutes on day two). 


\section{Workplace Observations}

During our visits, we made observations related to employees' use of personal protective equipment (PPE), laser safety practices, and room pressurization. When performing laser tattoo removals, dermatologists wore nitrile gloves, a molded surgical mask (Figure 1), and laser protective eyewear (LPE). Employees reported that the manufacturer of the laser provided all LPE to the center. The center also had laser masks available for voluntary wear. The laser masks were different from the molded surgical masks and were marketed as protective against plumes during laser surgery, but they were not NIOSH-certified respirators. We learned that employees voluntarily wore the laser masks during hair removal procedures and that the decision whether to wear them was made by the employee. There was no mandatory respiratory protection program for the clinic.

All LPE was stored in plastic bins in the same room as the laser they were intended to protect against. It was difficult to read optical density and wavelength on some pairs of LPE. Therefore, employees may not be able to confirm whether the worn LPE will protect against the wavelengths. Each patient examination room was labeled with appropriate signage and had an operational "laser in use" sign. These signs were illuminated (turned on) for the entire work shift, even when the laser was not in use. Employees relied on knocking and listening to determine whether to enter the examination room. Leaving the signs illuminated throughout the work day defeats the purpose of the signs. Entering an examination room without appropriate LPE can increase the risk of eyes being exposed to lasers. Keeping worn LPE in the workplace without knowing the shelf life could also increase the chances of inadvertent eye exposures, as the effectiveness of LPE decreases over time. All laser machines were independently labeled as inspected annually by the hospital.

We observed that the examination rooms were negative pressurized relative to the hallway, using ventilation smoke tubes. This means that air flowed from the hallway and into the examination room. The negative pressure airflow is in agreement with our findings for metals, VOC's, and particles. We did not observe any evidence that the emissions from the laser tattoo removals were migrating out of the patient exam rooms.

We observed a dermatologist using a smoke evacuator during laser hair removal procedures (Figure 6). The workplace has two types of smoke evacuators that use the same kind of filter. The filter has four stages: (1) pre-filter for larger particles; (2) an ultra-low penetration air filter; (3) activated carbon bed; and (4) a foam section that prevents activated carbon particles from migrating out of the filter. There is a lighted display that indicates filter life and suction power. The suction tube is held next to the laser probe during the procedures. Dermatologists reported that one of the major benefits to using the smoke evacuators during laser hair removal was that it helped to control odors during hair removal procedures. Although this health hazard evaluation request was not focused on hair removal, employees questioned whether the smoke evacuators were necessary during tattoo removals. 


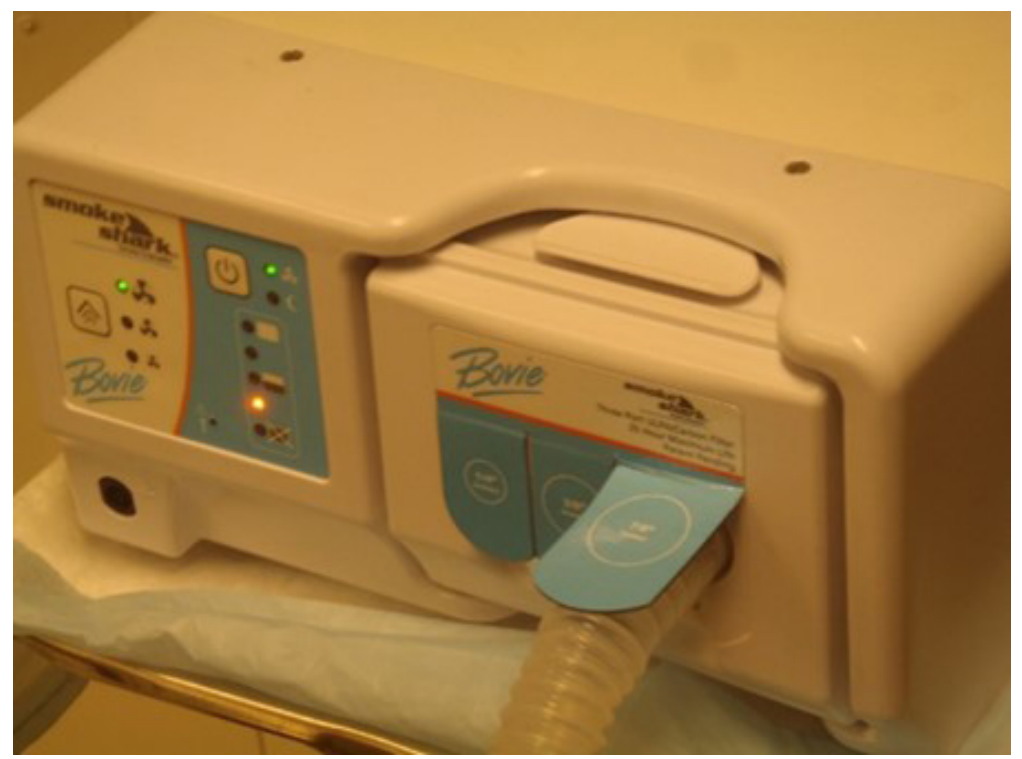

Figure 6. One of the smoke evacuators used during laser hair removal. They are located in the same rooms that the laser tattoo removals occur.

\section{Conclusions}

We evaluated exposures associated with laser tattoo removal at a hospital dermatology center. Although we were able to measure low levels of some metals, VOCs, bacteria, and particles, none of our results were above applicable OELs. Our results do not indicate that respiratory protection is required. We observed that the laser safety program could be strengthened to include replacing LPE when it has become worn out and new practices around the "laser in use" signs. We also observed that the voluntary use masks available to employees were not certified by NIOSH.

\section{Recommendations}

On the basis of our findings, we recommend the actions listed below. We encourage the dermatology center to use a labor-management health and safety committee or working group to discuss our recommendations and develop an action plan. Those involved in the work can best set priorities and assess the feasibility of our recommendations for the specific situation at the office.

Our recommendations are based on an approach known as the hierarchy of controls (Appendix E). This approach groups actions by their likely effectiveness in reducing or removing hazards. In most cases, the preferred approach is to eliminate hazardous materials or processes and install engineering controls to reduce exposure or shield employees. Until such controls are in place, or if they are not effective or feasible, administrative measures and PPE may be needed. 


\section{Administrative Controls}

The term administrative controls refers to employer-dictated work practices and policies to reduce or prevent hazardous exposures. Their effectiveness depends on employer commitment and employee acceptance. Regular monitoring and reinforcement are necessary to ensure that policies and procedures are followed consistently.

1. Contact the manufacturers of the different lasers in the center to establish shelf life, storage conditions, and appropriate cleaning methods for laser safety eyewear as described in the American National Standards Institute (ANSI) standard Z136.3 Section 4.6.2.

2. Utilize the signs indicating "laser in use" only when lasers are being used.

3. Use smoke evacuators to help control nuisance odors. Use the existing smoke evacuators in a manner consistent with how it is used during laser hair removal.

\section{Personal Protective Equipment}

PPE is the least effective means for controlling hazardous exposures. Proper use of PPE requires a comprehensive program and a high level of employee involvement and commitment. The right PPE must be chosen for each hazard. Supporting programs such as training, change-out schedules, and medical assessment may be needed. PPE should not be the sole method for controlling hazardous exposures. Rather, PPE should be used until effective engineering and administrative controls are in place.

1. Discontinue use of the laser masks and molded surgical masks for respiratory protection. If employees want to use respirators on a voluntary use basis, use NIOSHapproved filtering facepiece respirators (such as an N95).

2. Contact your Department of Environmental Health and Safety to ensure that you are in compliance with the voluntary use provisions of the OSHA respiratory protection standard (29 CFR 1910.134) if you plan to wear filtering facepiece respirators during tattoo removal. We found no evidence that respiratory protection should be required.

3. Ensure that all LPE is clearly labeled with the optical density and wavelength that the eyewear protects against as described in ANSI standard Z163.3 Section 4.6.2.3. Any eyewear with faded or missing information should be discarded.

4. Only purchase and provide respirators certified by NIOSH. The list of NIOSHapproved N95 respirators can be found here:

https://www.cdc.gov/niosh/npptl/topics/respirators/disp_part/n95list1.html. 


\section{Appendix A: Target Analytes and Minimum Detectable and Quantifiable Concentrations}

Table A1. Table of target analytes for bulk ink analysis (milligrams per kilogram of ink)

\begin{tabular}{|c|c|c|}
\hline Analyte & $\begin{array}{l}\text { Minimum detectable } \\
\text { concentration* }\end{array}$ & $\begin{array}{l}\text { Minimum quantifiable } \\
\text { concentration* }\end{array}$ \\
\hline Aluminum & 5 & 15 \\
\hline Antimony & 5 & 14 \\
\hline Arsenic & 5 & 16 \\
\hline Barium & 2 & - \\
\hline Beryllium & 0.06 & 0.18 \\
\hline Cadmium & 0.2 & 0.77 \\
\hline Calcium & 20 & 74 \\
\hline Chromium & 0.3 & 1.0 \\
\hline Cobalt & 0.6 & 1.8 \\
\hline Copper & 0.3 & 0.85 \\
\hline Iron & 9 & 37 \\
\hline Lanthanum & 0.3 & 1.0 \\
\hline Lead & 6 & - \\
\hline Lithium & 0.4 & 1.3 \\
\hline Magnesium & 0.8 & 2.8 \\
\hline Manganese & 0.6 & 2.0 \\
\hline Molybdenum & 0.6 & 2.1 \\
\hline Nickel & 0.7 & 2.6 \\
\hline Phosphorus & 40 & 120 \\
\hline Potassium & 0.9 & 3.8 \\
\hline Selenium & 9 & 36 \\
\hline Silver & 0.5 & - \\
\hline Strontium & 0.09 & 0.31 \\
\hline Tellurium & 3 & 9.3 \\
\hline Thallium & 2 & 7.0 \\
\hline Tin & 30 & 81 \\
\hline Titanium & 0.9 & 3.9 \\
\hline Vanadium & 0.5 & 1.5 \\
\hline Yttrium & 0.03 & 0.093 \\
\hline Zinc & 9 & 31 \\
\hline Zirconium & 0.09 & 0.30 \\
\hline
\end{tabular}

*These values varied slightly from sample to sample.

The most conservative numbers are listed here. 
Table A2. Table of target analytes for metals in air samples during tattoo removal (in $\mu \mathrm{g} / \mathrm{m}^{3}$ )

\begin{tabular}{|c|c|c|}
\hline Analyte & $\begin{array}{l}\text { Minimum detectable } \\
\text { concentration* }\end{array}$ & $\begin{array}{l}\text { Minimum quantifiable } \\
\text { concentration* }^{*}\end{array}$ \\
\hline Aluminum & $0.8-2$ & $2.8-5.2$ \\
\hline Antimony & $0.2-3$ & $4.5-8.4$ \\
\hline Arsenic & $0.2-2$ & $2.9-7.9$ \\
\hline Barium & $0.2-0.4$ & $0.51-1.2$ \\
\hline Beryllium & $0.01-0.02$ & $0.03-0.05$ \\
\hline Cadmium & $0.03-0.1$ & $0.11-0.20$ \\
\hline Calcium & $30-50$ & 93-190 \\
\hline Chromium & $0.3-0.5$ & $0.85-2.2$ \\
\hline Cobalt & $0.1-0.3$ & $0.32-1.1$ \\
\hline Copper & $0.2-0.5$ & $0.64-1.5$ \\
\hline Iron & $2-10$ & $8.5-26$ \\
\hline Lanthanum & $0.02-0.1$ & $0.08-0.35$ \\
\hline Lead & $0.5-2$ & $1.7-5.0$ \\
\hline Lithium & $0.06-0.3$ & $0.17-0.90$ \\
\hline Magnesium & $5-10$ & $19-38$ \\
\hline Manganese & $0.03-0.2$ & $0.11-0.73$ \\
\hline Molybdenum & $0.1-0.4$ & $0.45-1.3$ \\
\hline Nickel & $0.1-0.3$ & $0.35-0.89$ \\
\hline Phosphorus & $0.8-2$ & $2.5-53$ \\
\hline Potassium & $0.8-2$ & $2.7-5.2$ \\
\hline Selenium & $3-10$ & $8.5-33$ \\
\hline Silver & $0.05-0.1$ & $0.20-0.39$ \\
\hline Strontium & $0.1-0.2$ & $0.34-0.63$ \\
\hline Tellurium & $0.8-3$ & $2.9-7.9$ \\
\hline Thallium & $2-5$ & $5.6-16$ \\
\hline Tin & $0.8-2$ & $2.6-5.2$ \\
\hline Titanium & $0.1-0.2$ & $0.34-0.72$ \\
\hline Vanadium & $0.3-0.5$ & $1.3-2.4$ \\
\hline Yttrium & $0.01-0.04$ & $0.03-0.13$ \\
\hline Zinc & $0.3-0.5$ & $1.0-2.3$ \\
\hline Zirconium & $0.03-0.1$ & $0.09-0.17$ \\
\hline
\end{tabular}

*These values varied slightly from sample to sample.

The most conservative numbers are listed here. 
Table A3. Table of target analytes for VOCs in air samples during tattoo removal from pig skin (in ppb)

\begin{tabular}{|c|c|c|}
\hline Analyte & $\begin{array}{l}\text { Minimum detectable } \\
\text { concentration* }\end{array}$ & $\begin{array}{l}\text { Minimum quantifiable } \\
\text { concentration* }\end{array}$ \\
\hline 1,1,1-Trichloroethane & $0.08-4$ & $1.2-15$ \\
\hline 1,1,2,2-Tetrachloroethane & $0.2-4$ & $1.2-15$ \\
\hline 1,1,2-Trichloroethane & $0.1-4$ & $1.2-15$ \\
\hline 1,1-Dichloroethane & $0.1-4$ & $1.2-15$ \\
\hline 1,1-Dichloroethene & $0.1-4$ & $1.2-15$ \\
\hline 1,2,4-Trichlorobenzene & $0.4-4$ & $1.2-15$ \\
\hline 1,2,4-Trimethylbenzene & $0.1-4$ & $1.2-15$ \\
\hline 1,2-Dibromoethane & $0.09-4$ & $1.2-15$ \\
\hline 1,2-Dichlorobenzene & $0.2-4$ & $1.2-15$ \\
\hline 1,2-Dichloroethane & $0.1-4$ & $1.2-15$ \\
\hline 1,2-Dichloropropane & $0.08-4$ & $1.2-15$ \\
\hline 1,3,5-Trimethylbenzene & $0.2-4$ & $1.2-15$ \\
\hline 1,3-Butadiene & $0.6-4$ & $1.2-15$ \\
\hline 1,3-Dichlorobenzene & $0.1-4$ & $1.2-15$ \\
\hline 1,4-Dichlorobenzene & $0.2-4$ & $1.2-15$ \\
\hline 1,4-Dioxane & $0.2-4$ & $1.2-15$ \\
\hline 2,2,4-Trimethylpentane & $0.05-4$ & $1.2-15$ \\
\hline 2-Butanone & $0.1-4$ & $1.2-15$ \\
\hline 2-Hexanone & $0.1-4$ & $1.2-15$ \\
\hline 4-Ethyltoluene & $0.2-4$ & $1.2-15$ \\
\hline 4-Methyl-2-pentanone & $0.1-4$ & $1.2-15$ \\
\hline Acetone & $0.7-4$ & $1.2-15$ \\
\hline Allyl chloride & $0.1-4$ & $1.2-15$ \\
\hline Benzene & $0.09-4$ & $1.2-15$ \\
\hline Benzyl chloride & $0.07-4$ & $1.2-15$ \\
\hline Bromodichloromethane & $0.1-4$ & $1.2-15$ \\
\hline Bromoethene & $0.6-4$ & $1.2-15$ \\
\hline Bromoform & $0.1-4$ & $1.2-15$ \\
\hline Bromomethane & $0.4-4$ & $1.2-15$ \\
\hline Carbon disulfide & $0.1-4$ & $1.2-15$ \\
\hline Carbon tetrachloride & $0.07-4$ & $1.2-15$ \\
\hline Chlorobenzene & $0.1-4$ & $1.2-15$ \\
\hline Chloroethane & $0.6-4$ & $1.2-15$ \\
\hline Chloroform & $0.08-4$ & $1.2-15$ \\
\hline Chloromethane & $0.2-4$ & $1.2-15$ \\
\hline cis-1,2-dichloroethene & $0.08-4$ & $1.2-15$ \\
\hline cis-1,3-dichloropropene & $0.2-4$ & $1.2-15$ \\
\hline Cyclohexane & $0.4-4$ & $1.2-15$ \\
\hline
\end{tabular}

Note: see table notes on the following page 
Table A3 (continued). Table of target analytes for VOCs in air samples during tattoo removal from pig skin (in ppb)

\begin{tabular}{|c|c|c|}
\hline Analyte & $\begin{array}{l}\text { Minimum detectable } \\
\text { concentration* }\end{array}$ & $\begin{array}{l}\text { Minimum quantifiable } \\
\text { concentration* }\end{array}$ \\
\hline Dibromochloromethane & $0.08-4$ & $1.2-15$ \\
\hline Dichlorodifluoromethane & $0.2-4$ & $1.2-15$ \\
\hline Dichlorotetrafluoroethane & $0.9-4$ & $1.2-15$ \\
\hline Ethyl acetate & $0.1-4$ & $1.2-15$ \\
\hline Ethylbenzene & $0.2-4$ & $1.2-15$ \\
\hline Heptane & $0.1-4$ & $1.2-15$ \\
\hline Hexachlorobutadiene & $0.3-4$ & $1.2-15$ \\
\hline Hexane & $0.1-4$ & $1.2-15$ \\
\hline Isopropyl alcohol & $500-900$ & $1,400-1,700$ \\
\hline m \& p-Xylene & $0.3-4$ & $1.2-15$ \\
\hline Methyl tert-butyl ether & $0.1-4$ & $1.2-15$ \\
\hline Methylene chloride & $0.09-4$ & $1.2-15$ \\
\hline Naphthalene & $0.6-9$ & $2.4-29$ \\
\hline o-Xylene & $0.2-4$ & $1.2-15$ \\
\hline Propene & $0.3-4$ & $1.2-15$ \\
\hline Styrene & $0.2-4$ & $1.2-15$ \\
\hline Tetrachloroethene & $0.2-4$ & $1.2-15$ \\
\hline Tetrahydrofuran & $0.3-4$ & $1.2-15$ \\
\hline Toluene & $0.1-4$ & $1.2-15$ \\
\hline trans-1,2-dichloroethene & $0.08-4$ & $1.2-15$ \\
\hline trans-1,3-dichloropropene & $0.1-4$ & $1.2-15$ \\
\hline Trichloroethene & $0.1-4$ & $1.2-15$ \\
\hline Trichlorofluoromethane & $0.3-4$ & $1.2-15$ \\
\hline Trichlorotrifluoroethane & $0.08-4$ & $1.2-15$ \\
\hline Vinyl acetate & $0.08-4$ & $1.2-15$ \\
\hline Vinyl chloride & $0.7-4$ & $1.2-15$ \\
\hline
\end{tabular}

*These values varied slightly from sample to sample. The most conservative numbers are listed here. 


\section{Appendix B: Bacterial 16S rDNA Amplification, Cloning, and Sanger Sequencing}

We amplified bacterial 16S ribosomal DNA (rDNA) sequences using the highly conserved primer pair p8FPL (AGTTTGATCCTGGCTCAG) and p806R (GGACTACCAGGGTATCTAAT) as previously described [Broadwater et al. 2016; McCabe et al. 1999]. We amplified the bacterial 16S rRNA genes with Invitrogen Platinum Taq DNA polymerase by a modified method of [McCabe et al. 1999]. The polymerase chain reaction (PCR) conditions included initial denaturation at $95^{\circ} \mathrm{C}$ for 4 minutes, followed by 33 cycles of denaturation at $94^{\circ} \mathrm{C}$ for 1 minute, annealing at $55^{\circ} \mathrm{C}$ for 1 minute, extension at $72^{\circ} \mathrm{C}$ for 2 minutes, and completion with a final extension at $72^{\circ} \mathrm{C}$ for 10 minutes. We ran three 50 microliters replicate PCR reactions for each sample with the use of 5 microliters of DNA template. We combined the replicates, and the rDNA amplicons were purified with a Qiagen PCR purification kit according to the manufacturer's instructions. We ran the purified product ( 8 microliters) on a 1\% agarose gel containing 1 microgram per milliliter ethidium bromide and examined for amplicons with ultraviolet light.

We cloned bacterial amplicons into the pDRIVE vector using a Qiagen PCR cloning kit. We generated clone libraries by transforming cloned plasmids into chemically competent Escherichia coli cells as previously described [Broadwater et al. 2016]. We selected positive colonies (as determined colorimetrically by the inactivation of the lacZ gene) and cultured for 16 hours at $37^{\circ} \mathrm{C}$ in liquid Luria-Bertani media containing 100 micrograms per milliliter of ampicillin. Resultant cells were centrifuged at $1800 \times \mathrm{g}$ (relative centrifugal force) and the pellet resuspended in 200 microliters of 15\% glycerol, and sent for Sanger sequencing of the bacterial $16 \mathrm{~S}$ insert from Genewiz, Inc. Inserts were sequenced in both directions, allowing for sequence analysis of the $16 \mathrm{~S}$ region.

Sequencing results were downloaded as ".ab1" chromatogram files from Genewiz Inc. Vector sequence data were trimmed and forward and reverse sequences were assembled using Biomatters Geneious R7 Software. Then we sequenced the DNA to identify which varieties of bacteria were present in the air. Sequence data were then clustered into operational taxonomic units with MOTHUR software version 1.32.1 using a 97\% similarity cutoff as described in previous publications [Broadwater et al. 2016; Schloss et al. 2009]. Sequences representative of each taxonomic unit were then used in a Basic Local Alignment Search Tool search against the National Center for Biotechnology Information database to identify the bacterial species present. 


\section{Appendix C: Tattoo Removal Information}

Table C1. Information about tattoo removals from pig skin

\begin{tabular}{lcccc}
\hline $\begin{array}{l}\text { Number in } \\
\text { Figure 1 }\end{array}$ & Tattoo color & $\begin{array}{c}\text { Laser wavelength } \\
(\mathrm{nm})\end{array}$ & Laser pulse rate & $\begin{array}{c}\text { Tattoo removal } \\
\text { duration (minutes) }\end{array}$ \\
\hline 1 & Black & 1,064 & 750 picoseconds & 6 \\
2 & Black & 1,064 & 2 nanoseconds & 7 \\
3 & Yellow & 532 & 750 picoseconds & 5 \\
4 & Yellow & 532 & 2 nanoseconds & 8 \\
5 & Red & 532 & 750 picoseconds & 7 \\
6 & Red & 532 & 2 nanoseconds & 6 \\
7 & Green & 755 & 4 nanoseconds & 6 \\
8 & Green & 1,064 & 750 picoseconds & 1 \\
9 & Green & 532 & 2 nanoseconds & 1 \\
10 & Green & 532 & 750 picoseconds & 4 \\
11 & Blue & 755 & 4 nanoseconds & 5 \\
12 & Blue & 1,064 & 750 picoseconds & 4 \\
\hline
\end{tabular}

Table C2. Information about tattoo removals from patients

\begin{tabular}{lcccc}
\hline $\begin{array}{l}\text { Tattoo } \\
\text { number }\end{array}$ & Tattoo color & $\begin{array}{c}\text { Laser wavelength } \\
(\mathrm{nm})\end{array}$ & Laser pulse rate & $\begin{array}{c}\text { Tattoo removal } \\
\text { duration (minutes) }\end{array}$ \\
\hline 1 & Black & 1,064 & 750 picoseconds & 8 \\
2 & Black & 1,064 & 750 picoseconds & 3 \\
3 & Black & 1,064 & 750 picoseconds & 3 \\
4 & Black & 1,064 & 750 picoseconds & 19 \\
4 & Red & 532 & Q-switch & 6 \\
4 & Yellow & 532 & Q-switch & 5 \\
4 & Blue & 694 & Q-switch & 8 \\
4 & Blue & 694 & Q-switch & 3 \\
5 & Blue/Green & 694 & Q-switch & 13 \\
6 & Black & 1,064 & 750 picoseconds & 3 \\
\hline
\end{tabular}




\section{Appendix D: Supplementary Table for Bulk Tattoo Ink Analysis}

Table D1. Bulk results for elements in various colors of ink (milligrams per kilogram of ink)*

\begin{tabular}{|c|c|c|c|c|c|c|}
\hline Analyte & Blue ink & Red ink & Black ink & Yellow ink & Light green ink & Light blue ink \\
\hline Aluminum & ND & 50 & ND & 360 & 1,300 & 7,600 \\
\hline Barium & ND & [6.5] & ND & [5.3] & [5.0] & ND \\
\hline Cadmium & ND & {$[0.46]$} & {$[0.24]$} & ND & ND & ND \\
\hline Calcium & 130 & 190 & ND & [50] & 97 & [68] \\
\hline Chromium & 2.1 & 3.9 & 1.4 & ND & 2.2 & {$[0.75]$} \\
\hline Cobalt & ND & ND & ND & [1.0] & {$[1.2]$} & 4.2 \\
\hline Copper & 22,000 & 3.0 & 0.97 & {$[0.43]$} & 5,500 & 4,900 \\
\hline Iron & [14] & 41 & {$[9.7]$} & ND & [32] & ND \\
\hline Lead & [17] & ND & ND & ND & ND & ND \\
\hline Lithium & [0.33] & ND & ND & ND & ND & [13] \\
\hline Magnesium & 9.6 & 21 & 4.6 & 32 & 38 & ND \\
\hline Manganese & 3.7 & ND & ND & ND & ND & 14 \\
\hline Molybdenum & 56 & ND & ND & ND & ND & 13 \\
\hline Nickel & [0.82] & ND & ND & ND & {$[0.75]$} & [1.3] \\
\hline Phosphorus & 1,600 & [95] & ND & [100] & 630 & 460 \\
\hline Potassium & ND & 7.2 & 130 & 7.8 & 24 & 5.3 \\
\hline Silver & {$[1.8]$} & ND & ND & ND & [1.5] & [9.2] \\
\hline Strontium & [0.26] & 1.9 & {$[0.15]$} & 0.56 & 2.8 & [0.29] \\
\hline Tellurium & ND & ND & ND & ND & ND & [3.9] \\
\hline Thallium & 12 & [2.6] & [2.0] & [3.1] & [2.9] & ND \\
\hline Titanium & [1.2] & 130 & ND & 620 & 650 & 2,600 \\
\hline Vanadium & ND & ND & ND & ND & ND & 2.2 \\
\hline Yttrium & [0.077] & [0.052] & ND & ND & [0.052] & ND \\
\hline Zinc & [25] & ND & ND & ND & ND & ND \\
\hline Zirconium & 7.6 & 7.1 & 6.2 & 63 & 150 & 1,400 \\
\hline
\end{tabular}

[ ] = Estimated concentration; this concentration was between the minimum detectable concentration and the minimum quantifiable concentration.

*The minimum quantifiable concentrations are listed in Appendix A, Table A1. 


\section{Appendix E: Occupational Exposure Limits and Health Effects}

NIOSH investigators refer to mandatory (legally enforceable) and recommended OELs for chemical, physical, and biological agents when evaluating workplace hazards. OELs have been developed by federal agencies and safety and health organizations to prevent adverse health effects from workplace exposures. Generally, OELs suggest levels of exposure that most employees may be exposed to for up to 10 hours per day, 40 hours per week, for a working lifetime, without experiencing adverse health effects. However, not all employees will be protected if their exposures are maintained below these levels. Some may have adverse health effects because of individual susceptibility, a pre-existing medical condition, or a hypersensitivity (allergy). In addition, some hazardous substances act in combination with other exposures, with the general environment, or with medications or personal habits of the employee to produce adverse health effects. Most OELs address airborne exposures, but some substances can be absorbed directly through the skin and mucous membranes.

Most OELs are expressed as a time weighted average exposure. A time weighted average refers to the average exposure during a normal 8- to 10-hour workday. Some chemical substances and physical agents have recommended short-term exposure limit or ceiling values. Unless otherwise noted, the short term exposure limit is a 15-minute time weighted average exposure. It should not be exceeded at any time during a workday. The ceiling limit should not be exceeded at any time.

In the United States, OELs have been established by federal agencies, professional organizations, state and local governments, and other entities. Some OELs are legally enforceable limits; others are recommendations.

- The U.S. Department of Labor OSHA Permissible Exposure Limits (29 CFR 1910 [general industry]; 29 CFR 1926 [construction industry]; and 29 CFR 1917 [maritime industry]) are legal limits. These limits are enforceable in workplaces covered under the Occupational Safety and Health Act of 1970.

- NIOSH Recommended Exposure Limits are recommendations based on a critical review of the scientific and technical information and the adequacy of methods to identify and control the hazard. NIOSH Recommended Exposure Limits are published in the NIOSH Pocket Guide to Chemical Hazards [NIOSH 2010]. NIOSH also recommends risk management practices (e.g., engineering controls, safe work practices, employee education/training, PPE, and exposure and medical monitoring) to minimize the risk of exposure and adverse health effects.

- Another set of OELs commonly used and cited in the United States is the ACGIH Threshold Limit Values (TLVs). The TLVs are developed by committee members of this professional organization from a review of the published, peer-reviewed literature. TLVs are not consensus standards. They are considered voluntary exposure guidelines for use by industrial hygienists and others trained in this discipline "to assist in the control of health hazards" [ACGIH 2018]. 
Outside the United States, OELs have been established by various agencies and organizations and include legal and recommended limits. The Institut für Arbeitsschutz der Deutschen Gesetzlichen Unfallversicherung (Institute for Occupational Safety and Health of the German Social Accident Insurance) maintains a database of international OELs from European Union member states, Canada (Québec), Japan, Switzerland, and the United States. The database, available at http://www.dguv.de/ifa/GESTIS/GESTIS-Internationale-Grenzwerte-fürchemische-Substanzen-limit-values-for-chemical-agents/index-2.jsp, contains international limits for more than 2,000 hazardous substances and is updated periodically.

OSHA requires an employer to furnish employees a place of employment free from recognized hazards that cause or are likely to cause death or serious physical harm [Occupational Safety and Health Act of 1970 (Public Law 91-596, sec. 5(a)(1))]. This is true in the absence of a specific OEL. It also is important to keep in mind that OELs may not reflect current health-based information.

When multiple OELs exist for a substance or agent, NIOSH investigators generally encourage employers to use the lowest OEL when making risk assessment and risk management decisions. NIOSH investigators also encourage use of the hierarchy of controls approach to eliminate or minimize workplace hazards. This includes, in order of preference, the use of (1) substitution or elimination of the hazardous agent, (2) engineering controls (e.g., local exhaust ventilation, process enclosure, dilution ventilation), (3) administrative controls (e.g., limiting time of exposure, employee training, work practice changes, medical surveillance), and (4) PPE (e.g., respiratory protection, gloves, eye protection, hearing protection). Control banding, a qualitative risk assessment and risk management tool, is a complementary approach to protecting employee health. Control banding focuses on how broad categories of risk should be managed. Information on control banding is available at http://www.cdc.gov/niosh/topics/ctrlbanding/. This approach can be applied in situations where OELs have not been established or can be used to supplement existing OELs. 


\section{Appendix F: Supplementary Tables for Volatile Organic Compound Results}

Table F1. Instantaneous air sample for VOCs near the pig skin with black tattoo ink (in ppb) ${ }^{*} \dagger$

\begin{tabular}{|c|c|c|}
\hline Analyte & $\begin{array}{l}\text { Picosecond } \\
\text { laser }\end{array}$ & $\begin{array}{c}\text { Nanosecond } \\
\text { laser }\end{array}$ \\
\hline 1,2,4-Trimethylbenzene & {$[0.14]$} & {$[0.14]$} \\
\hline 1,3-Butadiene & ND & 1.6 \\
\hline 2-Butanone & 1.0 & {$[0.72]$} \\
\hline Acetone & 27 & 56 \\
\hline Benzene & {$[0.58]$} & 1.5 \\
\hline Carbon disulfide & ND & {$[0.24]$} \\
\hline Chloroform & {$[0.12]$} & ND \\
\hline Chloromethane & {$[0.78]$} & {$[0.70]$} \\
\hline Dichlorodifluoromethane & {$[0.50]$} & {$[0.52]$} \\
\hline Ethyl acetate & [0.23] & {$[0.16]$} \\
\hline Ethylbenzene & {$[0.29]$} & {$[0.30]$} \\
\hline Heptane & {$[0.12]$} & [0.12] \\
\hline Hexane & {$[0.25]$} & {$[0.24]$} \\
\hline Isopropyl alcohol & 15,000 & 26,000 \\
\hline m \& p-Xylene & {$[0.91]$} & {$[0.66]$} \\
\hline Methylene chloride & {$[0.27]$} & {$[0.24]$} \\
\hline o-Xylene & {$[0.29]$} & {$[0.24]$} \\
\hline Propene & 2.0 & 6.4 \\
\hline Styrene & ND & 1.1 \\
\hline Toluene & [0.89] & 1.2 \\
\hline Trichlorofluoromethane & {$[0.41]$} & {$[0.62]$} \\
\hline
\end{tabular}

[ ] = Estimated concentration; this concentration was between the minimum detectable concentration and the minimum quantifiable concentration.

*The minimum quantifiable concentrations are listed in Appendix A, Table A3.

†The duration of this sample was approximately 30 seconds. 
Table F2. Instantaneous air sample for VOCs near the pig skin with yellow tattoo ink (in ppb) ${ }^{*} \dagger$

\begin{tabular}{lcc}
\hline Analyte & $\begin{array}{c}\text { Picosecond } \\
\text { laser }\end{array}$ & $\begin{array}{c}\text { Nanosecond } \\
\text { laser }\end{array}$ \\
\hline 1,2,4-Trimethylbenzene & {$[0.14]$} & {$[0.13]$} \\
1,3-Butadiene & 1.8 & 4.6 \\
2-Butanone & {$[0.70]$} & {$[0.79]$} \\
Acetone & 77 & 30 \\
Benzene & 1.1 & 1.8 \\
Carbon disulfide & $\mathrm{ND}$ & {$[0.19]$} \\
Chlorobenzene & $\mathrm{ND}$ & {$[0.13]$} \\
Chloromethane & {$[0.98]$} & 1.1 \\
Dichlorodifluoromethane & 1.2 & {$[0.49]$} \\
Ethyl acetate & {$[0.16]$} & {$[0.13]$} \\
Ethylbenzene & {$[0.22]$} & {$[0.28]$} \\
Heptane & {$[0.14]$} & {$[0.15]$} \\
Hexane & {$[0.24]$} & {$[0.25]$} \\
Isopropyl alcohol & 45,000 & 59,000 \\
m \& p-Xylene & {$[0.62]$} & {$[0.62]$} \\
Methylene chloride & {$[0.60]$} & {$[0.25]$} \\
Naphthalene & 12 & ND \\
o-Xylene & {$[0.26]$} & {$[0.32]$} \\
Propene & 4.5 & 9.0 \\
Styrene & {$[0.32]$} & {$[0.55]$} \\
Toluene & 1.2 & 1.6 \\
Trichlorofluoromethane & {$[0.80]$} & {$[0.83]$} \\
\hline I E Estimated concentation & this & \\
\hline
\end{tabular}

[ ] = Estimated concentration; this concentration was between the minimum detectable concentration and the minimum quantifiable concentration.

*The minimum quantifiable concentrations are listed in Appendix A, Table A3.

†The duration of this sample was approximately 30 seconds. 
Table F3. Instantaneous air sample for VOCs near the pig skin with red tattoo ink (in ppb) ${ }^{*} \dagger$

\begin{tabular}{|c|c|c|}
\hline Analyte & $\begin{array}{c}\text { Picosecond } \\
\text { laser }\end{array}$ & $\begin{array}{c}\text { Nanosecond } \\
\text { laser }\end{array}$ \\
\hline 1,2,4-Trimethylbenzene & {$[0.27]$} & [0.12] \\
\hline 1,3-Butadiene & 14 & 3.2 \\
\hline 1,4-Dichlorobenzene & {$[0.55]$} & ND \\
\hline 2,2,4-Trimethylpentane & ND & [0.18] \\
\hline 2-Butanone & ND & {$[0.55]$} \\
\hline 4-Methyl-2-pentanone & {$[0.14]$} & ND \\
\hline Acetone & 49 & 31 \\
\hline Benzene & 24 & 2.7 \\
\hline Carbon disulfide & {$[0.25]$} & {$[0.12]$} \\
\hline Chlorobenzene & [0.69] & ND \\
\hline Chloromethane & 2.2 & {$[0.81]$} \\
\hline Dichlorodifluoromethane & {$[0.51]$} & {$[0.53]$} \\
\hline Ethyl acetate & {$[0.35]$} & {$[0.20]$} \\
\hline Ethylbenzene & 1.2 & [0.32] \\
\hline Heptane & {$[0.18]$} & {$[0.14]$} \\
\hline Hexane & {$[0.27]$} & {$[0.22]$} \\
\hline Isopropyl alcohol & 10,000 & 9,800 \\
\hline m \& p-Xylene & 1.2 & {$[0.55]$} \\
\hline Methylene chloride & [0.31] & {$[0.32]$} \\
\hline Naphthalene & [0.59] & ND \\
\hline o-Xylene & {$[0.55]$} & {$[0.22]$} \\
\hline Propene & 34 & 6.7 \\
\hline Styrene & 29 & 4.0 \\
\hline Tetrahydrofuran & {$[0.45]$} & ND \\
\hline Toluene & 6.3 & 1.3 \\
\hline Trichlorofluoromethane & {$[0.78]$} & {$[0.81]$} \\
\hline Vinyl chloride & {$[0.59]$} & ND \\
\hline
\end{tabular}

[ ] = Estimated concentration; this concentration was between the minimum detectable concentration and the minimum quantifiable concentration.

*The minimum quantifiable concentrations are listed in Appendix A, Table A3.

†The duration of this sample was approximately 30 seconds. 
Table F4. Instantaneous air sample for VOCs near the pig skin with green tattoo ink (in ppb) ${ }^{*} \dagger$

\begin{tabular}{|c|c|c|}
\hline Analyte & $\begin{array}{c}755 \mathrm{~nm} \\
\text { wavelength }\end{array}$ & $\begin{array}{c}532 \mathrm{~nm} \\
\text { wavelength }\end{array}$ \\
\hline 1,2,4-Trichlorobenzene & {$[0.54]$} & ND \\
\hline 1,2,4-Trimethylbenzene & {$[0.18]$} & ND \\
\hline 1,2-Dichlorobenzene & {$[0.36]$} & ND \\
\hline 1,3-Butadiene & 42 & ND \\
\hline 1,3-Dichlorobenzene & {$[0.26]$} & ND \\
\hline 1,4-Dichlorobenzene & {$[0.16]$} & ND \\
\hline $2,2,4$-Trimethylpentane & {$[0.26]$} & ND \\
\hline 2-Butanone & {$[0.84]$} & ND \\
\hline Acetone & 36 & ND \\
\hline Benzene & 37 & ND \\
\hline Benzyl chloride & {$[0.78]$} & ND \\
\hline Carbon disulfide & 2.2 & ND \\
\hline Chlorobenzene & 11 & ND \\
\hline Chloroethane & {$[0.70]$} & ND \\
\hline Chloromethane & 13 & ND \\
\hline Dichlorodifluoromethane & {$[0.52]$} & ND \\
\hline Ethyl acetate & {$[0.40]$} & ND \\
\hline Ethylbenzene & 3.6 & ND \\
\hline Hexane & {$[0.38]$} & ND \\
\hline Isopropyl alcohol & 13,000 & 13,000 \\
\hline m \& p-Xylene & {$[0.80]$} & ND \\
\hline Methylene chloride & {$[0.54]$} & ND \\
\hline Naphthalene & 3.7 & ND \\
\hline o-Xylene & [0.68] & ND \\
\hline Propene & 110 & ND \\
\hline Styrene & 69 & ND \\
\hline Toluene & 14 & ND \\
\hline Trichlorofluoromethane & {$[0.72]$} & ND \\
\hline Vinyl chloride & 2.9 & ND \\
\hline
\end{tabular}

[ ] = Estimated concentration; this concentration was between the minimum detectable concentration and the minimum quantifiable concentrations.

${ }^{*}$ The minimum quantifiable concentrations are listed in Appendix A, Table A3.

†The duration of this sample was approximately 30 seconds. 
Table F5. Instantaneous air sample for VOCs near the pig skin with dark blue tattoo ink and a wavelength of $755 \mathrm{~nm}$ (in ppb)* ${ }^{*}$

\begin{tabular}{lc}
\hline Analyte & Result \\
\hline 1,2,4-Trimethylbenzene & {$[0.14]$} \\
1,3-Butadiene & 11 \\
2,2,4-Trimethylpentane & {$[0.18]$} \\
2-Butanone & {$[0.86]$} \\
Acetone & 63 \\
Benzene & 26 \\
Carbon disulfide & {$[0.22]$} \\
Chloromethane & 1.0 \\
Dichlorodifluoromethane & {$[0.50]$} \\
Ethyl acetate & {$[0.26]$} \\
Ethylbenzene & 1.5 \\
Heptane & {$[0.16]$} \\
Hexane & {$[0.26]$} \\
Isopropyl alcohol & 14,000 \\
m \& p-Xylene & {$[0.68]$} \\
Methylene chloride & {$[0.32]$} \\
Naphthalene & {$[1.7]$} \\
o-Xylene & {$[0.40]$} \\
Propene & 35 \\
Styrene & 54 \\
Toluene & 6.5 \\
Trichlorofluoromethane & {$[0.60]$} \\
\hline
\end{tabular}

[ ] = Estimated concentration; this concentration was between the minimum detectable concentration and the minimum quantifiable concentration.

*The minimum quantifiable concentrations are listed in Appendix A, Table A3.

†The duration of this sample was approximately 30 seconds. 
Table F6. Instantaneous air sample for VOCs during removal of black tattoos using a wavelength of $1,064 \mathrm{~nm}$ (in ppb) ${ }^{*} \dagger$

\begin{tabular}{lccccc}
\hline Analyte & Tattoo 1 & Tattoo 2 & Tattoo 3 & Tattoo 4 & Tattoo 5 \\
\hline Acetone & 28 & 29 & 29 & 28 & {$[1.1]$} \\
Ethyl acetate & {$[2.2]$} & {$[2.1]$} & {$[1.8]$} & {$[1.6]$} & 54 \\
Ethylbenzene & 7.3 & 6.7 & 5.9 & 5.3 & {$[1.6]$} \\
Isopropyl alcohol & 3,600 & 4,400 & 4,100 & 4,300 & 7.0 \\
m \& p-Xylene & 20 & 19 & 17 & 15 & 4,400 \\
o-Xylene & 4.4 & 4.0 & {$[3.6]$} & {$[3.2]$} & 21 \\
\hline
\end{tabular}

[ ] = Estimated concentration; this concentration was between the minimum detectable concentration and the minimum quantifiable concentration.

*The minimum quantifiable concentrations are listed in Appendix A, Table A3.

†The duration of this sample was approximately 30 seconds.

Table F7. Instantaneous air sample for VOCs during removal of a red tattoo using a wavelength of $532 \mathrm{~nm}$ (in ppb) ${ }^{*} \dagger$

\begin{tabular}{lc}
\hline Analyte & Result \\
\hline Acetone & {$[230]$} \\
Ethyl acetate & {$[1.3]$} \\
Ethylbenzene & 4.1 \\
Isopropyl alcohol & 6,200 \\
$\mathrm{~m} \& \mathrm{p}-X y l e n e$ & 12 \\
o-Xylene & {$[2.5]$} \\
\hline
\end{tabular}

[ ] = Estimated concentration; this concentration was between the minimum detectable concentration and the minimum quantifiable concentration.

${ }^{*}$ The minimum quantifiable concentrations are listed in Appendix A, Table A3.

†The duration of this sample was approximately 30 seconds. 
Table F8. Instantaneous air sample for VOCs during removal of a yellow tattoo using a wavelength of $532 \mathrm{~nm}$ (in ppb)* $\dagger$

\begin{tabular}{lc}
\hline Analyte & Result \\
\hline Acetone & 46 \\
Ethyl acetate & {$[1.2]$} \\
Ethylbenzene & 3.9 \\
Isopropyl alcohol & 7,100 \\
m \& p-Xylene & 11 \\
o-Xylene & {$[2.4]$} \\
Propene & {$[1.9]$} \\
\hline
\end{tabular}

[ ] = Estimated concentration; this concentration was between the minimum detectable concentration and the minimum quantifiable concentration.

*The minimum quantifiable concentrations are listed in Appendix A, Table A3.

†The duration of this sample was approximately 30 seconds.

Table F9. Instantaneous air sample for VOCs during removal of blue/green tattoos using a wavelength of $694 \mathrm{~nm}$ (in ppb) ${ }^{*} \dagger$

\begin{tabular}{lcc}
\hline Analyte & Tattoo 1 & Tattoo 2 \\
\hline Acetone & 38 & 35 \\
Ethyl acetate & {$[1.6]$} & {$[2.0]$} \\
Ethylbenzene & 4.8 & 9.0 \\
Isopropyl alcohol & 7,600 & 3,200 \\
m \& p-Xylene & 14 & 27 \\
o-Xylene & {$[3.0]$} & 6.1 \\
Propene & {$[1.8]$} & $\mathrm{ND}$ \\
Toluene & $\mathrm{ND}$ & {$[1.7]$} \\
\hline
\end{tabular}

[ ] = Estimated concentration; this concentration was between the minimum detectable and minimum quantifiable concentration.

${ }^{*}$ The minimum quantifiable concentrations are listed in Appendix A, Table A3.

†The duration of this sample was approximately 30 seconds. 


\section{References}

ACGIH [2001]. Documentation of the threshold limit values and biological exposure indices, 7th ed. Cincinnati, OH: American Conference of Governmental Industrial Hygienists.

ACGIH [2018]. 2018 TLVs ${ }^{\circledR}$ and BEIs ${ }^{\circledR}$ : threshold limit values for chemical substances and physical agents and biological exposure indices. Cincinnati, OH: American Conference of Governmental Industrial Hygienists.

Broadwater K, de Perio MA, Roberts J, Burton NC, Lemons AR, Green BJ, Brueck SE [2016]. Investigating a persistent odor at an aircraft seat manufacturer. JOEH 13(10):D159D165, https://doi.org/10.1080/15459624.2016.1183017.

CFR. Code of Federal Regulations. Washington, DC: U.S. Government Printing Office, Office of the Federal Register.

Chuang GS, Farinelli W, Christiani DC, Herrick RF, Lee NCY, Avram MM [2016]. Gaseous and particulate content of laser hair removal plume. JAMA Dermatol 152(12):1320-1326, https://doi.org/10.1001/jamadermatol.2016.2097.

EPA [1999]. Compendium method TO-15, determination of volatile organic compounds (VOCs) in air collected in specially-prepared canisters and analyzed by gas chromatography/mass spectrometry (GC/MS). In: Compendium of methods for the determination of toxic organic compounds in ambient air. Cincinnati, $\mathrm{OH}$ : Center for Environmental Research Information, Office of Research and Development, U.S. Environmental Protection Agency, Publication No. EPA/625/R-96/010b, https://www3.epa.gov/ttnamti1/files/ambient/airtox/to-15r.pdf.

Forte G, Petrucci F, Cristuado A, Bocca B [2009]. Market survey on toxic metals contained in tattoo inks. Sci Total Environ 407(23):5997-6002, https://doi.org/10.1016/j.scitotenv.2009.08.034.

Grant CA, Twigg PC, Baker, R, Tobin DJ [2015]. Tattoo ink nanoparticles in skin tissue and fibroblasts. Beilstein J Nanotechnol 6:1183-1191, https://doi.org/10.3762/bjnano.6.120.

Grice EA, Kong HH, Renaud G, Young AC, NISC CSP, Bouffard GG, Blakesley RW, Wilfberg TG, Turner ML, Segre JA [2008]. A diversity profile of the human skin microbiota. Genome Res 18:1043-1050, https://doi.org/10.1101/gr.075549.107.

Grice EA, Segre JA [2011]. The skin microbiome. Nat Rev Microbiol 9:244-253, https://doi.org/10.1038/nrmicro2537.

Ho DD, London R, Zimmerman GB, Young DA [2002]. Laser-tattoo removal - a study of the mechanism and the optimal treatment strategy via computer simulations. Lasers Surg Med 30:389-397, https://doi.org/10.1002/1sm.10065.

Lindsley WG, Schmechel D, Chen BT [2006]. A two-stage cyclone using microcentrifuge tubes for personal bioaerosol sampling. J Environ Monit 8(11):1136-1142, https://doi.org/10.1039/b609083d. 
McCabe KM, Zhang YH, Huang BL, Wagar EA, McCabe ERB [1999]. Bacterial species identification after DNA amplification with a universal primer pair. Mol Genet Metab 66(3):205-211, http://dx.doi.org/10.1006/mgme.1998.2795.

NIOSH [2010]. NIOSH pocket guide to chemical hazards. Cincinnati, OH: U.S. Department of Health and Human Services, Centers for Disease Control and Prevention, National Institute for Occupational Safety and Health, DHHS (NIOSH) Publication No. 2010-168c, http://www.cdc.gov/niosh/npg/.

NIOSH [2018]. NIOSH manual of analytical methods (NMAM). 5th ed. O'Connor PF, Ashley K, eds. Cincinnati, OH: U.S. Department of Health and Human Services, Centers for Disease Control and Prevention, National Institute for Occupational Safety and Health, DHHS (NIOSH) Publication No. 2014-151, http://www.cdc.gov/niosh/nmam.

Riordan T [2007]. Human infection with Fusobacterium necrophorum (necrobacillosis), with a focus on lemierre's syndrome. Clin Microbiol Rev 20(4):622-659, https://doi.org/10.1128/cmr.00011-07.

Sawchuck WS, Weber PJ, Lowy DR, Dzubow LM [1989]. Infectious papillomavirus in the vapor of warts treated with carbon dioxide laser or electrocoagulation: detection and protection. J Am Acad Dermatol 21(1):41-49, https://doi.org/10.1016/s0190-9622(89)70146-8.

Schloss PD, Westcott SL, Ryabin T, Hall JR, Hartmann M, Hollister EB, Lesniewski RA, Oakley BB, Parks DH, Robinson CJ, Sahl JW, Stres B, Thallinger GG, Van Horn DJ, Weber CF [2009]. Introducing mothur: open-source, platform-independent, community-supported software for describing and comparing microbial communities. Appl Environ Microbiol 75(23):7537-7541, http://dx.doi.org/10.1128/AEM.01541-09. 
Keywords: North American Industry Classification System (NAICS) 621111 (Offices of Physicians [except Mental Health Specialists]), Massachusetts, Laser, Tattoo Removal, Dermatology, Metals, Particles, Bacteria, Fungi, Volatile Organic Compounds 
The Health Hazard Evaluation Program investigates possible health hazards in the workplace under the authority of the Occupational Safety and Health Act of 1970 (29 U.S.C. § 669(a) (6)). The Health Hazard Evaluation Program also provides, upon request, technical assistance to federal, state, and local agencies to investigate occupational health hazards and to prevent occupational disease or injury. Regulations guiding the Program can be found in Title 42, Code of Federal Regulations, Part 85; Requests for Health Hazard Evaluations (42 CFR Part 85).

\section{Disclaimer}

The recommendations in this report are made on the basis of the findings at the workplace evaluated and may not be applicable to other workplaces.

Mention of any company or product in this report does not constitute endorsement by NIOSH.

Citations to Web sites external to NIOSH do not constitute NIOSH endorsement of the sponsoring organizations or their programs or products. NIOSH is not responsible for the content of these Web sites. All Web addresses referenced in this document were accessible as of the publication date.

\section{Acknowledgments}

Analytical Support: Maxxam Analytics

Desktop Publisher: Shawna Watts

Editor: Ellen Galloway

Logistics: Donnie Booher, Kevin Moore

\section{Availability of Report}

Copies of this report have been sent to the employer and employees at the facility. The state and local health department and the Occupational Safety and Health Administration Regional Office have also received a copy. This report is not copyrighted and may be freely reproduced.

\section{Recommended citation for this report:}

NIOSH [2018]. Characterizing exposures during laser tattoo removal in a hospital dermatology center. By Grant MP, Glassford E, Green B, Lemons A. Cincinnati, OH: U.S. Department of Health and Human Services, Centers for Disease Control and Prevention, National Institute for Occupational Safety and Health, Health Hazard Evaluation Report 2017-0006-3319, https://www.cdc.gov/niosh/hhe/reports/pdfs/2017-0006-3319.pdf. 
Delivering on the Nation's promise:

Promoting productive workplaces through safety and health research

To receive NIOSH documents or more information about occupational safety and health topics, please contact NIOSH:

Telephone: 1-800-CDC-INFO (1-800-232-4636)

TTY: 1-888-232-6348

CDC INFO: www.cdc.gov/info

or visit the NIOSH Web site at www.cdc.gov/niosh

For a monthly update on news at $\mathrm{NIOSH}$, subscribe to

$\mathrm{NIOSH}$ eNews by visiting www.cdc.gov/niosh/eNews. 